\title{
Mezinárodněprávní aspekty nekalé soutěže a nekalých obchodních praktik v právu Evropské unie
}

\section{Unfair Competition and Unfair Commercial Practices and Their Regulation in EU Private International Law}

\author{
David Sehnálek*
}

\begin{abstract}
Abstrakt
Svoboda pobybu zboži a postupujici harmonizace vnitrostátního hmotnébo práva právem Evropské unie usnadñuje preshranični transakce. Rozvoji obchodu dále napomábá elektroniz̨ace služeb a intenżivnèjsí využivání internetu. Problémy, které v minulosti bylo možno résit takr̉ka výlučně nebo alespoň vétšinově na národni úrovni, nyni ziskávaji mezinárodni charakter. Mnohdy to bude diisledek zámèrnébo jednáni podnikatele, vyloučena ale neni ani nechtèná aktivace zabraničního práva či sudistě. V tuzemské odborné literature neni vènována dostatečná pozornost mezinárodnèprávním aspektuim nekalé soutěž a nekalých obchodnich praktik. Právě na nè je proto tento článek zamèren. S obledem na žretelný vliv práva Evropské unie, které národni kolizni a procesni normy nahradilo vlastni unifikovanou unijni úpravou, je ₹koumána unijni regulace této problematiky, a to ve svétle judikatury Soudníbo dvora EU. Cílem je identifikovat rizika spojená s úpravou proti nekalosoutěžnimu jednáni s preshraničním dopadem a vymezit pravidla pro určeni rozhodného práva a mista sudistě.
\end{abstract}

\section{Klíčová slova}

Nekalá soutě̌̌; nekalé obchodni praktiky; mezinárodni právo sonkromé; rozhodné právo; sudištè.

\section{Abstract}

The free movement of goods and the ongoing harmonisation between national substantive law and the European Union law facilitates cross-border transactions. Computerisation of services and intensified use of the Internet also contribute to the development of trade. Problems that could once be addressed almost exclusively or at least prevailingly at a national level are presently assuming an international character. This is true also in case of regulation of unfair competition and unfair commercial practices. This topic is, however, not fully examined in the Czech scientific literature when it comes to its private international law and procedure dimension. Since the EU law has to a large extent replaced national conflict-of-law rules and rules of procedure with unified EU provisions, this article is focused primarily on the EU law regulation, including the case law of the Court of Justice EU. The objective of this article is to identify risks related to the regulation of unfair competition with cross-border implications and to determine the governing law and jurisdiction.

Keywords

Unfair Competition' Unfair Commercial Practices; Private International Law; Governing Law; Jurisdiction.

* JUDr. David Sehnálek, Ph.D., odborný asistent, Katedra mezinárodního a evropského práva, Právnická fakulta, Masarykova univerzita, Brno; advokát, Brno / Department of International and European Law, Faculty of Law, Masaryk University, Brno, Czech Republic / E-mail: david.sehnalek@gmail.com 


\section{Úvodem}

Tento článek ${ }^{1}$ je zaměřen na problematiku nekalé soutěže a nekalých obchodních praktik při přeshraničním obchodování v Evropské unii. Skutečností je, že obchod je v současné době do značné míry globalizován. ${ }^{2}$ Přispěla $\mathrm{k}$ tomu řada faktorů, a to jak právních, tak i neprávních. Mezi ty právní nepochybně patří právo Evropské unie, zejména ta jeho část, která upravuje fungování vnitřního trhu. Vliv svobod jednotného vnitřního trhu Evropské unie na obchod zbožím a službami mezi členskými státy a jeho neustále vzrůstající intenzitu je nepopiratelný. $\mathrm{K}$ snazšímu, a tedy i četnějšímu přeshraničnímu obchodu, přispívá rovněž harmonizace vnitrostátního práva unijním právem, nebot’ je nástrojem eliminace bariér obchodu vyplývajících z rozdílných vnitrostátních úprav. Př́kladem faktoru neprávního je fenomén internetu a s ním související elektronizace řady činností, včetně prodeje zboží a služeb. Internet je v dnešní době zcela samozřejmě a běžně využíván pro podnikatelské účely především jako levný a rychlý prostředek šíření obchodních sdělení, reklamy, ${ }^{3}$ nástroj komunikace mezi obchodníkem a spotřebitelem, kontraktační nástroj, jakož i prostředek vlastního plnění smlouvy.

Harmonizace právem Evropské unie nemá komplexní charakter, raada oblastí vnitrostátního práva zůstává i nadále v pravomoci vnitrostátních zákonodárců. Jednou z oblastí, která sice harmonizována je, ale jen částečně, je problematika nekalé soutěže a nekalých obchodních praktik. V neharmonizované oblasti je proto pro osoby využívající výhod vnitřního trhu obtížné cílit své aktivity na jednotlivé trhy. Ekonomické požadavky totiž vedou zpravidla k centralizaci a unifikaci produkce. V neharmonizované oblasti práva je však nezbytné cílené přizpůsobování zboží, služeb, reklamy a prodejních praktik místním legislativním požadavkům. Jinak se totiž vcelku reálně může stát, že jednání př́pustné v jednom státě, bude, aniž by se jakkoliv změnilo, vyhodnoceno jako nekalosoutěžní, a tudíž protiprávní ve státě jiném. Realita právní, zejména teritoriální podmíněnost práva a rozdílnost představ států o vhodném standardu úpravy se potkává s realitou ekonomickou, která trhy jednotlivých států vnímá spíše jako jeden homogenní celek. ${ }^{4}$

1 Článek vznikl v rámci řešení grantu „Vliv práva Evropské unie na českou regulaci nekalé soutěže a nekalých obchodních praktik“, č. GA14-20147S.

2 Zde je myšlena především globalizace $\mathrm{v}$ „malém“ omezená jen na prostor Evropské unie.

3 K významu reklamy a internetu viz stanovisko generálního advokáta Bota ze dne 8. záři 2016. Openbaar Ministerie proti Lucu Vanderborghtovi. Věc C-339/15, odst. 89.

4 Jakkoliv to neplatí absolutně, protože individuální preference a zvyky spotřebitelů se mezi jednotlivými státy mohou lišit. 
Praktickým důsledkem výše uvedeného je střet jednotlivých jurisdikcí v př́padě, že má nekalosoutěžní jednání určitého obchodníka přeshraniční dosah, a s tím spojená nutnost určení rozhodného práva a pravomocných (př́islušných) ${ }^{5}$ soudů.

Cílem tohoto článku je identifikovat možná rizika, která pro přeshraniční podnikání vyplývají z unijní úpravy nekalé soutěže a nekalých obchodních praktik, a to zejména v př́padě obchodování na internetu. Zaměřen bude na problematiku určení rozhodného práva a sudiště v mezinárodním právu soukromém a procesním Evropské unie. Výchozím předpokladem je, že právem Evropské unie harmonizované oblasti úpravy hrozbou v zásadě nejsou, jelikož se standardy mezi členskými státy nebudou výrazně lišit. Proto bude v první části článku pozitivně věcně vymezen rozsah unijním právem harmonizované úpravy nekalé soutěže a nekalých obchodních praktik. Následovat bude rozbor pravidel pro určení sudiště a rozhodného práva $\mathrm{v}$ evropském mezinárodním právu soukromém. Pozornost bude věnována judikatuře Soudního dvora EU. Ta se sice prímo netýká oblasti nekalé soutěže a nekalých obchodních praktik, úzce s ní ale souvisí. Cílem a prínosem článku má být její doktrinální uchopení a vysvětlení, proč se závěry v ní obsažené týkají také v článku zkoumané problematiky. Dovozena budou též obecná pravidla, podle kterých se místo sudiště a rozhodné právo v oblasti nekalé soutěže a nekalých obchodních praktik určuje.

\section{Obecné vymezení úpravy nekalé soutěže a nekalých obchodních praktik v právu Evropské unie}

Evropská unie v současné době nemá pravomoc regulovat komplexně nekalou soutěž, jako tak mohou činit prostřednictvím vlastního práva státy. Věcný záběr unijní úpravy nekalé soutěže proto nekoresponduje se záběrem úpravy této problematiky v \ 2972 OZ a násl. Máme-li proto sledovat systematiku české úpravy podle zvláštních skutkových podstat nekalé soutěže, pak lze konstatovat, že právo Evropské unie v současné době upravuje pouze klamavou reklamu a srovnávací reklamu ve směrnici 2006/114, ${ }^{6}$ nově pak též ochranu obchodního tajemství ve směrnici 2016/943. ${ }^{7}$

5 S pojmy „pravomoc“ a „př́slušnost“ je v právu Evropské unie problém. Unijní právo totiž pojem „př́islušnost“" používá tam, kde by právo české mezinárodní právo soukromé užilo pojem „pravomoc“. $\mathrm{V}$ tomto článku se budeme držet terminologie české doktríny, jakkoliv jsme si vědomi, že s ohledem na unijní rozměr této problematiky by stejně tak mohl a možná i měl být použit namísto pojmu „pravomoc“ pojem „př́slušnost" Srov. PAUKNEROVÁ, M. Europské mezinárodni právo soukromé. 1. vyd. Praha: C. H. Beck, 2008, 441 s., s. 133, dále též KYSELOVSKÁ, T., ROZEHNALOVÁ, N. a kol. Rozhodování Soudního dvora EU ve vécech prǐslušnosti (analýza roz̧bodnutí dle Nař̌zenei Brusel Ibis). 1. vyd. Brno: Masarykova univerzita, 2014, 514 s., s. 25; KUČERA, Z. Mezinárodni právo soukromé. 7. opravené a doplněné vyd. Plzeň: Aleš Čeněk, 2006, 464 s., s. 382 a ROZEHNALOVÁ, N., VALDHANS, J., DRLIČKOVÁ, K., KYSELOVSKÁ, T. Męinárodni právo soukromé Evropské unie (Nař̀zeni Řim I, Nař́zeni Řim II, Nařzeneni Brusel I). 1. vyd. Praha: Wolters Kluwer ČR, 2013, 448 s., s. 202.

6 Směrnice Evropského parlamentu a Rady 2006/114/ES ze dne 12. prosince 2006 o klamavé a srovnávací reklamě.

7 Směrnice Evropského parlamentu a Rady (EU) 2016/943 ze dne 8. června 2016 o ochraně nezveřejněného know-how a obchodních informací (obchodního tajemstvî) před jejich neoprávněným získáním, využitím a zpř́istupněním. 
Úzkou souvislost s výše uvedenými oblastmi má právní unijní úprava nekalých obchodních praktik ve směrnici $2005 / 29 .{ }^{8}$ V této směrnici ale není unijní úprava rozkročena do obou oblastí chráněných zájmů, tzn. ochrana není poskytována jak podnikatelům, tak i spotřebitelům, avšak soustřed’uje se jen na druhé uvedené. Podnikatelé ovšem v konečném důsledku i jejím prostřednictvím chráněni jsou, ale jen nepř́mo. Ochrana před nekalými obchodními praktikami se dále dotýká nejenom úpravy otázek jinak patř́cích do nekalé soutěže (např. řada zakázaných nekalých obchodník praktik se týká rovněž reklamy, zvlášt' je-li klamavá, prípadně je postižitelná podle generální klauzule nekalé soutěže), ale též smluvního práva (obrana proti zneužívajícím smluvním podmínkám).

Co unijní úpravě naopak chybí, je obecná a všezahrnující generální klauzule nekalé soutěže obdobná $\$ 2976$ odst. 1 OZ. I když, příměr by možná byl trefnější směrem $\mathrm{k}$ německému právu, které platnou unijní úpravu pokrývá v zásadě komplexně v rámci jednotné úpravy v zákoně proti nekalé soutěži. ${ }^{10}$

Z pohledu tohoto článku je dále podstatné především to, že charakter harmonizace je v různých oblastech unijní regulace nekalé soutěže různý. Požadavky týkající se nekalých obchodních praktik a srovnávací reklamy představují úplnou harmonizaci. Úprava klamavé reklamy je harmonizací minimální.

Z pohledu námi zkoumané problematiky nejsou relevantní oblasti již právem Evropské unie harmonizované. Zde je situace obchodníka jasná a standard právní úpravy v jiných členských státech relativně snadno zjistitelný a předvídatelný. $\mathrm{V}$ oblastech, které harmonizovány nejsou, anebo které jdou nad harmonizovaný minimální standard, vzniká nejistota ohledně právní úpravy daná tím, že se př́slušné standardy nachází výlučně $\mathrm{v}$ národním právu. Mezi členskými státy se tak mohou značně lišit. Proto je $\mathrm{v}$ př́ípadě přeshraniční činnosti mimořádně důležité určení rozhodného práva, podle kterého budou konkrétní situace posuzovány, jakož i určení soudů, které ř́zení povedou.

8 Směrnice Evropského parlamentu a Rady 2005/29/ES ze dne 11. května 2005 o nekalých obchodních praktikách vůči spotřebitelům na vnitřním trhu a o změně směrnice Rady 84/450/EHS, směrnic Evropského parlamentu a Rady 97/7/ES, 98/27/ES a 2002/65/ES a nařízení Evropského parlamentu a Rady (ES) č. 2006/2004 (směrnice o nekalých obchodních praktikách).

9 Spojení „obecná a všezahrnující je použito zcela záměrně s ohledem na existenci tzv. velké generální klauzule a tzv. generálních klauzulí malých ve směrnici 2009/25. Tyto generální klauzule však nejsou srovnatelné s tou českou dle \2976 odst. $1 \mathrm{OZ}$ - za prvé z důvodu omezení jejich personálního dosahu jen vztahy mezi spotřebiteli a obchodníky (B2C), za druhé z důvodu věcného omezení jen na oblast nekalých obchodních praktik. Všezahrnující charakter generální klauzule nekalé soutěže je patrný také z faktu, že v sobě dokáže „pohltit“ i celou oblast nekalých obchodních praktik skrze nepojmenovanou skutkovou podstatu „porušení norem veřejného práva se soutěžním dopadem“. K tomu srov. ONDREJOVÁ, D. Nekalá soutěž v novém občanském zákoníku. Komentár. Praha: C. H. Beck, 2014, s. 56 a násl.

10 Gesetz gegen den unlauteren Wettbewerb. Ke komparaci české a německé úpravy viz NAVRÁTIL, P. Generálni klauzule nekalé soutěže [cit. 25. 2. 2017]. Univerzita Karlova, Právnická fakulta. Dostupné z: http:// www.prf.cuni.cz/res/dwe-files/1404046095.pdf, s. 16-19. 
Směrnice 2006/114 a 2005/29 shodně požadují, aby členské státy vytvořily prostředky jejich prosazování. Soutěžitelé, spotřebitelé a třetí osoby, jež na tom mohou mít právní zájem, by měli mít možnost:

1. podat žalobu ohledně klamavé reklamy či v případě nedovolené srovnávací reklamy, jakož i v př́padě dotčení prostřednictvím nekalých obchodních praktik nebo

2. napadnout takovou reklamu nebo tyto nekalé obchodní praktiky u stanoveného nestranného správního orgánu. ${ }^{11}$

Požadavek existence mechanismů prosazování ze strany dotčených jednotlivců analogicky obsahuje též směrnice 943/2016. Tím se povinnosti členských států vyplývající z uvedených směrnic nevyčerpávají, zcela samozřejmě je totiž jejich povinností zajistit též veřejnoprávní vynucování směrnic bez vazby na podnět jednotlivce. Tato problematika ale přesahuje rámec námi vymezeného problému, a proto nebude dále zkoumána.

Úprava ve směrnicích je nastavena tak, že nespoléhá jen na aktivitu a pozornost státu, ale předpokládá též iniciativu dotčených spotřebitelů a dalších osob, prostřednictvím které bude možné obě směrnice prosazovat též soukromoprávní cestou. To je mimořádně důležité, nebot' tímto tlakem shora (ze strany veřejné moci) i zdola (ze strany jednotlivců) se pravděpodobnost, že cíle sledované unijní úpravou budou skutečně naplněny, výrazně zvyšuje.

Z pohledu tohoto článku je ovšem podstatné to, že výše uvedené požadavky směrnic nijak nesouvisí s problematikou mezinárodního práva soukromého a také z nich nevyplývá, kde a jak konkrétně, tedy ve kterém státě a podle jakého práva, bude směrnice prosazována. Není to ostatně jejich účelem, jelikož byly přijaty na základě článku 114 Smlouvy o fungování EU a nikoliv v rámci justiční spolupráce $\mathrm{v}$ občanských věcech podle článku 81 odst. 2 písm. c) téže smlouvy.

\section{Určení sudiště ve věcech nekalé soutěže a nekalých obchodních praktik}

Mezinárodní právo soukromé je Evropskou unií regulované v rámci politiky justiční spolupráce v občanských věcech. Tato politika není úzce navázána na základní svobody vnitřního trhu, jakkoliv i s nimi souvisí. Jestliže unijní hmotněprávní úprava nekalé soutěže zasahuje jen některé instituty, jelikož je přijímána na právním základě článku 114 Smlouvy o fungování EU, který komplexní úpravu dané problematiky vylučuje, pak unijní úprava mezinárodního práva soukromého dosahuje též na ty oblasti vnitrostátní úpravy nekalé soutěže, které harmonizací pravidel dotčeny nijak nebyly. Je prritom nerozhodné, zda unijnímu vlivu unikly $z$ důvodu absence pravomoci, či jen jejího nevykonání. Jinými slovy, z pohledu kompetenčního neexistuje překryv mezi pravomocí Evropské unie harmonizovat vnitrostátního právo na straně jed-

11 Viz článek 5 směrnice 2006/114 a článek 11 směrnice 2005/29. 
né a upravovat kolizní a procesní aspekty téže problematiky na straně druhé. I proto je tato kapitola zaměřena šířeji než předchozí.

Odlišná je též metoda regulace. $\mathrm{V}$ případě problematiky mezinárodního práva soukromého se totiž používají nařízení a nikoliv směrnice. Vnitrostátní právo v této oblasti bylo funkčně nahrazeno úpravou unijní. Pravidla pro určení sudiště v občanských a obchodních věcech ${ }^{12}$ jsou Evropskou unií unifikována nařízením Brusel I bis. ${ }^{13}$ Tento předpis sice nekalou soutěž explicitně nezmiňuje, jelikož se ale jedná o obchodněprávní problematiku, jež z jeho dosahu vyloučena není, je jím rovněž věcně upravena.

\subsection{Určení sudiště dle nařízení Brusel I bis - obecné pravidlo}

Obecné pravidlo pro určení pravomoci obsažené v čl. 4 odst. 1 nařízení Brusel I bis stanoví, že pravomocnými jsou soudy určené podle místa sídla žalovaného. Z pohledu praktického je toto pravidlo výhodné pro toho, kdo je v pozici pasivní, tedy kdo je žalován. Osoba aktivní, žalující, se mu ale zpravidla bude chtít vyhnout. Nařízení Brusel I bis takovou možnost dává. V čl. 7 odst. 2 totiž ve věcech týkajících se deliktní nebo kvazideliktní odpovědnosti, ${ }^{14}$ tedy typicky v oblasti nekalé soutěže, umožňuje žalobu podat u soudu místa, kde došlo nebo může dojít ke škodné události. ${ }^{15}$ Volba obou svým významem a vazbou $\mathrm{k}$ věci ekvivalentních řešení je přitom z povahy věci ponechána straně, která spor iniciuje, nebot' jen ta je schopna nejlépe zhodnotit, kde bude neúčelnější spor vést. Tato pravidla jsou zřetelným odrazem teoreticko-právního přístupu unijní úpravy mezinárodního práva soukromého, který nestaví na první místo zájem dotčených států, ale vychází spíše ze samé podstaty řešených problémů a účelu dotčené právní úpravy.

$12 \mathrm{~K}$ přesnému vymezení pojmu „občanské a obchodní věci“ srov. PAUKNEROVÁ, M. Evropské mez̧inárodni právo soukromé. 1. vyd. Praha: C. H. Beck, 2008, 441 s., s. 128 a násl.; dále též KYSELOVSKÁ, T., ROZEHNALOVÁ, N. a kol. Roz̧odováni Soudního dvora EU ve vécech prǒslušnosti (analýza rozhodnuti dle Nař̃zeni Brusel Ibis). 1. vyd. Brno: Masarykova univerzita, 2014, 514 s., s. 33 a násl.

13 Nařízení Evropského parlamentu a Rady (EU) č. 1215/2012 ze dne 12. prosince 2012 o prŕslušnosti a uznávání a výkonu soudních rozhodnutí v občanských a obchodních věcech.

14 Zahrnuty jsou „„ǔechny nároky, směrujici k uplatnèni odpovédnosti žalovaného, které nesouviseji se 'smlouvou' ve smyslu cl. [7] odst. 1 narizeni Brusel I [bis]". Viz PAUKNEROVÁ, M. Evropské mezinárodni právo soukromé. 1. vyd. Praha: C. H. Beck, 2008, 441 s., s. 141; a ROZEHNALOVÁ, N., VALDHANS, J., DRLIČKOVÁ, K., KYSELOVSKÁ, T. Mezinárodni právo soukromé Evropské unie (Naříni Rím I, Nař́zeni Rím II, Nařżeni Brusel I). 1. vyd. Praha: Wolters Kluwer ČR, 2013, 448 s., s. 245.

$15 \mathrm{~V}$ angloamerické právní oblasti jsou uplatňovány doktrinální přístupy rozdílné vycházející z „,testu skutečného a podstatného spojení“ (real and substantial connection test), které sice mohou být svým širokým záběrem pragmatičtější a flexibilnější ve srovnání s popsaným mechanickým přístupem unijního práva, ale jejich nevýhodou je jejich neurčitost a obtížná předvídatelnost výsledku. Široký záběr je následně zužován prostřednictvím jiných principů, jako je např. forum non conveniens. Srov. DYER, A. Unfair Competition in Private International Law. Recueil des Cours de l'Académie de droit international de La Haye. 1988, vol. 211, s. 441. 
Vrat'me se proto zpět k hmotněprávní úpravě nekalé soutěže a nekalých obchodních praktik. Veškeré výše uváděné směrnice mají něco společného, sledují určité cíle, v nichž se projevuje nejenom zájem soukromý, ale též zájem veřejný. Přijaty byly proto, aby zajistily funkčnost vnitřního trhu a soutěže na něm. Zde se projevuje především zájem veřejný, a to na ochraně volného přeshraničního obchodu zbožím a službami. Dotčeny jsou rovněž soukromé zájmy obchodníků na ochraně jejich práv, obdobně je dotčen též spotřebitel. Mezi postavením obchodníků a spotřebitelů je nicméně rozdíl. Obchodníci se zpravidla v námi sledované oblasti nachází v pozici třetí dotčené strany, tzn. mezi nimi a osobou, která se dopustila nekalosoutěžního jednání, typicky nevzniká smluvní vztah. Jednání nekalosoutěžně jednající osoby vưči spotřebiteli zpravidla ke vzniku smluvního vztahu vede, je však stiženo nějakou právní vadou (např. v prrípadě nekalých obchodních praktik opomenutím, klamáním, donucením apod.). Spojujícím faktorem obou situací je ovšem to, že dotčeny jsou ekonomické zájmy, a to jak obchodníků, tak i spotřebitelů.

Hmotněprávní unijní úprava nekalé soutěže je orientována na hospodářskou soutěž a s ní související ochranu spotřebitele. Jedno je přitom neoddělitelně spjaté s druhým. $\mathrm{K}$ pravidlům mezinárodního práva soukromého je proto nutné přistupovat tak, aby ochranu soutěže zahrnující rovněž zájmy spotřebitele také zajistila. V centru jeho pozornosti proto musí být protiprávní jednání obchodníka či zachování, resp. ochrana určitých práv dotčeného spotřebitele, zatímco irelevantní je povaha, resp. druh práva, jež bylo takovým protiprávním jednáním dotčeno, ${ }^{16}$ nebo smluvní typ spotřebitelské smlouvy, k jejímuž uzavření nekalá obchodní praktika směřovala, či plnění, které na jejím základě mělo být poskytnuto. Korektivem v oblasti procesní dále musí být zásada rádného a hospodárného soudního procesu, nebylo by totiž účelné vést spor tam, kde nelze dosáhnout jeho efektivního vyřešení.

Pro určení sudiště je rozhodné protiprávní jednání obchodníka, dưraz naopak není kladen např. na majetek či jim obdobná práva nekalosoutěžním jednáním dotčená. Takové jednání musí v určitém místě nastat (příčina, locus delicti commissi) a v určitém místě mohou nebo musí nastoupit jeho účinky (následek, locus damni infecti). Mezi těmito místy může být shoda, mohou se ale také nacházet v různých státech.

Ochrana dotčeným právům zcela logicky musí být poskytována tam, kde k jednání došlo, nebo tam, kde se jeho následek projevil. Jiné řešení by jen těžko mohlo být efektivní a vést k dosažení sledovaného cíle. Tím neříkáme, že by nebylo myslitelné či teoreticko-právně zdůvodnitelné. Lze si např́klad představit přístup, který bude určovat pravomoc podle hlediska zájmu státu. Ten by totiž nemusel existovat tehdy, pokud by protiprávní jednání účinky v daném státě nemělo vůbec, i když by právě zde došlo k protisoutěžnímu jednání. Takový prístup nicméně není v souladu s výše naznačenou koncepcí, na níž je nařízení Brusel I bis postaveno a kterou ostatně v našem právním prostoru považujeme za správnou.

16 DYER, A. Unfair Competition in Private International Law. Recueil des Cours de l'Académie de droit international de La Haye, 1988, vol. 211, s. 386. 
Na první pohled jasné pravidlo čl. 7 odst. 2 nařízení Brusel I bis v sobě nicméně skrývá určitá úskalí. Místo škodné události je totiž pojem, který lze interpretovat různým způsobem. Za takové místo lze považovat jak stát, kde bylo fakticky protiprávně jednáno, např. tím, že zde byla zveřejněna klamavá, př́ípadně srovnávací reklama či nepravdivá informace o soutěžiteli nebo jeho výrobcích a službách, stejně tak jím ale může být též stát jiný, pokud se $\mathrm{v}$ něm škoda projevila kupříkladu snížením zisku, poškozením dobrého jména či ztrátou obchodní př́ležitosti. V podmínkách jednání prostřednictvím internetu pak bude místo škodné události vưbec obtížné určit, potenciálně mohou účinky jednání nastoupit kdekoli, tudíž takovým místem může být kterákoliv lokace kdekoliv na světě, což ale z povahy věci nemůže být správný závěr. Odporoval by ostatně i účelu, pro který bylo nařízení Brusel I bis přijato. ${ }^{17}$ Problém se nadto dále komplikuje, uvážíme-li též současnou realitu obchodních vztahů, kdy v důsledku provázání jednotlivých soutěžitelů může mít újma podnikatele jednoho nepřímý vliv např. na pověst jiného, s ním propojeného, který má ale sídlo v jiném státě. ${ }^{18,19}$

Odpovědi na výše uvedené otázky lze dovodit z judikatury Soudního dvora EU. Poněkud problematický je však fakt, že dosud vydaná rozhodnutí se netýkají přímo problematiky nekalé soutěže. Zdá se totiž, jako by tato oblast regulace stála mimo sféru hlavního zájmu národních soudů kladoucích předběžné otázky. Dalším problémem je skutečnost, že řada rozhodnutí Soudního dvora EU se vztahuje k legislativě, jež stávající úpravu předcházela. Odlišný věcný záběr rozhodnutí je nicméně mnohdy irelevantní, a to proto, že dopad interpretovaných ustanovení je často obecný a může se se týkat i dalších oblastí, jež jsou předmětem regulace nařízením Brusel I bis. ${ }^{20}$ Fakt, že je v těchto rozhodnutích interpretována předcházející legislativa, pak také není př̀kážkou, a to proto, že v námi sledované oblasti $\mathrm{k}$ zásadním změnám ${ }^{21} \mathrm{v}$ úpravě nedošlo. ${ }^{22}$ Úprava nová nadto sama deklaruje kon-

17 Dotčen je princip předvídatelnosti řešení zmiňovaný nap̌r. v odst. 15 preambule nařízení Brusel I bis. Viz též HRNČIŔIIKOVÁ, M., RYŠAVÝ, L. Mezinárodni právo soukromé. Procesni otázky. 1. vyd. Olomouc: Univerzita Palackého v Olomouci, 2014, 250 s., s. 69.

18 Tak např. $\mathrm{v}$ situacích, kdy jsou dotčeny společnosti dceřiné, může negativní důsledky pocítit též společnost mateřská a naopak. $V$ dnešním globalizovaném světě přitom není výjimkou, že obě společnosti majî své sídlo v různých státech.

19 Nad rámec výše nastíněných právních problémů se nabízí další otázka, a totiž zda v situaci, kdy je určitým nekalosoutěžním jednáním dotčeno více soutěžitelů, mají tito možnost dle svého uvážení volit mezi jednotlivými sudišti, či zda jsou vzájemně vázáni již podanými návrhy, resp. volbou sudiště, kterou učinil napřs. první z nich, určitě by bylo možno identifikovat problémy a otázky další.

20 Jinými slovy odmítáme kazuistický př́stup ve prospěch abstrakce.

21 Formulace jsou stejné. Více k problému viz ROZEHNALOVÁ, N., VALDHANS, J., DRLIČKOVÁ, K., KYSELOVSKÁ, T. Mezinárodni právo soukromé Evropské unie (Nařzeneni Řim I, Nařzeni Rím II, Nař̌reni Brusel I). 1. vyd. Praha: Wolters Kluwer ČR, 2013, 448 s., s. 244.

22 Kontinuita je tak zajištěna už od Bruselské úmluvy z roku 1968. Viz též PAUKNEROVÁ, M. Evropské mezinárodní právo soukromé. 1. vyd. Praha: C. H. Beck, 2008, 441 s., s. 126. 
tinuitu s úpravou předcházející. ${ }^{23}$ Dřivější závěry Soudního dvora EU jsou proto obecně platné i dnes, ledaže by výslovně z legislativy či novější judikatury vyplýval opak. ${ }^{24}$

Pokud jde o určení místa vzniku škody, ${ }^{25}$ výklad článku 7 odst. 2 nařízení Brusel I bis připouští obě předestřené možnosti. $\mathrm{K}$ tomuto závěru dospěl Soudní dvůr EU v rozhodnutí Shevill, ${ }^{26} \mathrm{v}$ němž byla řešena otázka škody způsobené pomluvou v tisku distribuovaném mezinárodně, tedy ve více různých státech. V tomto rozhodnutí Soudní dvůr EU konstatoval, že v takovém př́padě je místem, kde došlo ke vzniku škody, to místo, kde je dotyčný vydavatel usazen, jelikož právě zde došlo k protiprávnímu jednání, jež je příčinou vzniklé škody. Dále dovodil, že místem, kde se škoda projevila, je také to místo, kde byl tisk distribuován za předpokladu, že zde byl poškozený znám. Právě zde se totiž projevily účinky protiprávního jednání. ${ }^{27} \mathrm{~V}$ obou prŕpadech je založena pravomoc soudů vést $\mathrm{v}$ dané věci řízení, její rozsah je ale rozdîlný. Soud určený podle místa protiprávního jednání je oprávněn projednat celý př́pad v plném rozsahu zpưsobené škody, zatímco soudy určené podle místa vzniku škody mohou projednat spor jen v rozsahu újmy způsobené v daném státě. ${ }^{28}$

\section{Zobecníme-li toto jinak velmi konkrétní řešení, pak platí, že Soudní dvůr EU sle- doval hledisko protiprávního (protisoutěžního) chování doplněné o hledisko}

23 Předcházející legislativou byla Bruselská úmluva z roku 1968 a nařízením č. 44/2001, tzv. nařízení Brusel I. Kontinuita výkladu je potvrzena nařízením Brusel I bis v odst. 38 jeho preambule.

24 Srov. rozsudek Soudního dvora (pátého senátu) ze dne 18. července 2013. ÖFAB, Östergötlands Fastigheter AB proti Frank Koot a Evergreen Investments BV. Věc C-147/12. Identifikátor ECLI: ECLI:EU:C:2013:490, odst. 28.

25 Rozumí se škoda prrímá, kdy je mezi protiprávním jednáním a jejím vznikem příčinná souvislost. K problematice viz ROZEHNALOVÁ, N., TÝČ, V. Evropský justični prostor (v civilních otázkách). 1. vyd. Brno: Masarykova univerzita, 2003, 401 s., s. 209.

26 Rozsudek Soudního dvora ze dne 7. března 1995. Fiona Shevill, Ixora Trading Inc., Chequepoint SARL a Chequepoint International Ltd proti Presse Alliance SA. Věc C-68/93.

27 Více viz ROZEHNALOVÁ, N., VALDHANS, J., DRLIČKOVÁ, K., KYSELOVSKÁ, T. Mezinárodní právo soukromé Evropské unie (Nařzeni Rím I, Nařzeni Rím II, Nař́zeni Brusel I). 1. vyd. Praha: Wolters Kluwer ČR, 2013, 448 s., s. 251.

28 Považujeme za nutné upozornit, že v oblasti hospodářské soutěže (její veřejnoprávní části) obdobné omezení dovozeno nebylo. Soudy proto v obou naznačených situacích mohou projednat škodu, jež byla způsobena kupr. kartelovou dohodou v plném rozsahu. Jsme toho názoru, že důvod rozdílného př́stupu byl správně identifikován generálním advokátem Jääskinenem (přestože se ve svém stanovisku v konečných závěrech se Soudním dvorem EU neshodl), když ve svém stanovisku konstatoval, že se jeví užitečným zohlednit všechna místa, kde byl narušen trh porušením článku 101 Smlouvy o fungování EU, jelikož cílem pravidel práva hospodářské soutěže je chránit řádný průběh hospodářské činnosti, tedy zájem veřejný a nikoliv chránit individuální zájmy dané společnosti, jako je tomu v př́padě pomluv, ale i škody způsobené nekalosoutěžním jednáním. V oblasti hospodářské soutěže tento zájem naopak pokrývá celé území Evropské unie, což ospravedlňuje odlišný prrístup. Srov. stanovisko generálního advokáta N. Jääskinena přednesené dne 11. prosince 2014.

Cartel Damage Claims Hydrogen Peroxide SA (CDC) v. Evonik Degussa GmbH a další. Věc C-352/13. odst. 50. Pokud jde o reflexi v odborné literatuře viz např. Wurmnest, W., International jurisdiction in competition damages cases under the Brussels I Regulation: CDC Hydrogen Peroxide. Common Market Law Review, 2016, Issue 1, s. 242. 
zvláště úzké vazby mezi sporem a určitým státem. S ohledem na praktický postup v soudním řízení (možnosti a dostupnost v otázkách dokazovaní, doručování apod.) jen toto hledisko dostatečně ospravedlňuje založení pravomoci soudů výše uvedených států, nebot' právě takové řešení nejlépe zohledňuje požadavek řádného a hospodárného soudního procesu. ${ }^{29}$ Ten by nebyl naplněn, pokud by spor měl být veden ve státě jiném, kde takto úzká vazba na spor dána není. To samozřejmě neznamená, že by zde spor nemohl být fakticky řešen, nebylo by to ale účelné.

Případ Shevill se sice týkal jen pomluvy v tisku, závěry v něm obsažené jsou nicméně analogicky přenositelné též do oblasti nekalé soutěže. Vzato do důsledku, pomluva ve skutečnosti není problematice nekalé soutěže vzdálená, naopak s ní úzce souvisí. Nekalá soutěž jako právní kategorie totiž zahrnuje mimo jiné též ochranu pověsti soutěžitele, ${ }^{30}$ která může být poškozena nejenom přímo (pomluvou, nekalým srovnáním v reklamě apod.), ale též prostřednictvím dalších typicky nekalosoutěžních praktik jako např̀. vyvoláním nebezpečí záměny $\mathrm{v}$ případě zboží či služby (nekvalitní neznačkové zboží vydávající se za kvalitní zboží originálnî). V obou případech má být nadto aplikována jedna a ta samá právní norma, a to na podstatou obdobnou situaci. Při jejím výkladu musí být sledován identický požadavek řádného a hospodárného soudního procesu, jenž je naplněn jen tehdy, je-li místo vedení sporu úzce spojeno s řešenou věcí. Opět přitom platí, že možná jsou samožrejmě i řešení jiná. Jen plně neodpovídají smyslu a duchu právní úpravy a výše nastíněnému doktrinálnímu základu unijní úpravy pravidel pro určování pravomoci soudů.

Je-li rozhodujícím kritériem zvlášt’ úzká vazba k určitému státu a jejím projevem dle rozsudku Shevill je možnost vést soudní řízení tam, kde je protiprávně jednající (pomlouvajícî) osoba usazena, pak lze též dovodit pravomoc soudů státu usazení osoby, která se dopustila nekalosoutěžního jednání. Spojujícím faktorem obou situací je totiž místo usazení, jež lokalizuje protiprávně jednající osobu v prostoru a čase, a vzniklá škoda. Situace se liší jen tím, jakým jednáním škoda byla způsobena, jež ale pro jeho povahu nelze považovat za dostatečně distinktivní prvek, který by ospravedlňoval jiné právní řešení.

Tentýž závěr platí též pro druhé pravidlo dovozené v př́ipadu Shevill. Zakládá-li dle rozsudku zvlášt' úzkou vazbu účinek protiprávního pomlouvačného jednání, pak analogicky i v př́padě nekalosoutěžního jednání musí být založena pravomoc soudů toho státu, kde takový účinek nastal.

I zde ale musí platit stejná omezení, a proto výše uvedené tvrzení je platné jen za předpokladu, že se v tomto státě poškozený hospodářské soutěže účastnil. Požadavek účasti na hospodářské soutěži je obdobný rozhodnutím Shevill stanovenému požadavku zná-

29 Srov. rozsudek Soudního dvora (čtvrtého senátu) ze dne 21. května 2015. Cartel Damage Claims Hydrogen Peroxide SA (CDC) v. Evonik Degussa GmbH a další. Věc C-352/13, odst. 41.

30 DYER, A. Unfair Competition in Private International Law. Recueil des Cours de l'Académie de droit international de La Haye, 1988, vol. 211, s. 396 a násl. 
mosti v dotčeném státě a má stejný význam. Známost je totiž zajištěna zapojením do veřejného života $\mathrm{v}$ daném státě, což je z hlediska podstaty ekvivalentem účasti na hospodářské soutěži. I zde, stejně jako v předchozím př́ípadě, druh jednání, který vedl ke vniku škody, není nadán dostatečnou rozlišovací způsobilostí a nemá proto schopnost jednání v určitém místě ukotvit pro potřeby určení sudiště. Účinek protiprávního jednání naopak tuto schopnost bezpochyby má.

\subsection{Určení sudiště dle nařízení Brusel I bis - obrana proti nekalé soutěži v prostředí internetu}

Tato obecná pravidla je nutné dále konkretizovat tehdy, pokud dochází k nekalosoutěžnímu jednání prostřednictvím internetu. Fyzické aspekty jednání, které se tak výrazně projevily v rozhodnutí Shevill, jsou zde relativizovány. Jednání učiněné prostřednictvím internetu totiž může mít účinky kdekoliv ve světě a platí to jak pro jednání osoby, která se nekalosoutěžního jednání dopustila, tak i pro možné následky ve vztahu k osobě, jíž byla újma zpo̊sobena. Jinými slovy, z pohledu strany, která nekalosoutěžně jedná, mohou být jejím jednáním teoreticky dotčeny veškeré státy světa. ${ }^{31}$ Obdobně pak z pohledu osoby, která se proti nekalosoutěžnímu jednání brání, přichází v úvahu možnost požadovat ochranu kdekoliv na světě, jelikož prostřednictvím internetu kdekoliv na světě potenciálně působí nebo působit může. Tento př́stup by nicméně vedl ke zcela absurdním závěrům, totiž že spor může být veden prakticky kdekoliv, v jakémkoliv státě, čímž by byl popřen samotný smysl a účel existence nařízení Brusel I bis. Rovněž by bylo relativizováno pravidlo pro určení soudní pravomoci stanovené v čl. 7 odst. 2 nařízení Brusel I bis. Je nutné je proto odmítnout. Rizika jsou ostatně i faktická. Takto by totiž snadno mohla být opakovaná soudní řízení zneužita šikanozním způsobem, zvlášt' v kombinaci s instituty předběžných opatření. ${ }^{32}$

Řešení této situace lze opět dovodit z judikatury Soudního dvora EU vztahující se k pomluvě. V prŕpadu eDate Advertising Soudní dvưr EU posuzoval situace, kdy byla prostřednictvím internetových stránek šířena informace zasahující do osobnostních práv dotčených osob. Př́pad nebyl nijak komplikovaný z pohledu směrnice 2000/31, tedy pokud jde o určení osoby, která je odpovědná za šířené informace. Otázka totiž zněla, jak lze pravidla pro určení pravomoci adaptovat podmínkám prostoru internetu.

Jak generální advokát, tak i Soudní dvůr EU dovodili, že určovatel, jímž je distribuce, resp. šíření informace $\mathrm{v}$ podmínkách internetu, a všudypř́ítomnost obsahu zve-

31 Srov. rozsudek Soudního dvora (velkého senátu) ze dne 25. řína 2011. eDate Advertising GmbH a další v. X a Société MGN LIMITED. Spojené věci C-509/09 a C-161/10. ECLI:EU:C:2011:68. Odst. 46.

32 A nejde jen o možné dočasné omezení vyplývající vždy z povahy sporu, ale již samotný fakt, že je proti určitému subjektu vedené soudní řízení může mít značné negativní dopady, např. pokud jde o důvěru ze strany investorů (zejména v prrípadě začínajících podnikatelských projektů) či obchodních partnerů. 
řejněných informací ztrácí na důležitosti, ${ }^{33}$ a „,[N]avíc z. technickébo blediska není vช̌́dy možné tento rozsah šireni s určitosti a spoleblivosti kvantifikovat ve vątabu ke konkéétnímu členskému státu, a proto ani obodnotit újmu zpuisobenou výlučnè v tomto členském státè. “ ${ }^{34}$ Nutnou reakcí práva proto musí být upřesnění podmínek určení pravomoci. V centru pozornosti zůstává hledisko zvlášt' úzké vazby mezi sporem a určitým státem, která je v tomto rozhodnutí vymezena prostřednictvím „místa centra zájmư ${ }^{\star 635}$ újmou dotčené osoby. Zde pak tato osoba může žalovat na náhradu celé způsobené újmy. Problém spočívá $\mathrm{v}$ tom, zda je tento př́stup skutečně konzistentní s účelem nařízení Brusel I bis, ${ }^{36}$ oprávněně lze totiž namítat, že nikoliv. ${ }^{37} \mathrm{~V}$ prrípadě nekalé soutěže je místem centra zájmů ten stát, kde je dotčený soutěžitel usazen, případně stát jiný, kde má své místo podnikání nebo kde se účastní hospodářské soutěže. Žalovat je samozřejmě možné i ve státech jiných, pak již ale pouze s ohledem na újmu způsobenou v daném státě..$^{38}$

\subsection{Určení sudiště dle nařízení Brusel I bis - obrana proti nekalým obchodním praktikám}

Soukromoprávní prosazování hraje významnou roli při prosazování unijní úpravy nekalé soutěže a zákazu nekalých obchodních praktik. Jak směrnice 2006/114, tak i směrnice 2005/29 výslovně požadují, aby členské státy zajistily prostředky jejich prosazování prostřednictvím žaloby podané přímo jednotlivci, nebo jejich sdruženími ohledně klamavé reklamy či $\mathrm{v}$ prrípadě nedovolené srovnávací reklamy, jakož i v prípadě dotčení prostřednictvím nekalých obchodních praktik. ${ }^{39}$ Tento mechanismus prosazování práva Evropské unie zdola má řadu výhod. Dotčení jednotlivci jsou zpravidla osobně motivování porušování řešit, protože jsou to právě oni, kdo je protiprávním jednáním dotčen. Zároveň se jedná o mechanismus bezprostřední, a to hned ze dvou důvodů. Umožňuje

33 Viz stanovisko generálního advokáta - Cruz Villalón - 29 března 2011. eDate Advertising GmbH proti X (C-509/09) a Olivier Martinez a Robert Martinez proti MGN Limited (C-161/10). Spojené věci C-509/09 a C-161/10. odst. 44 až 47 a rozhodnutí eDate Advertising odst. 46.

34 Rozhodnutí eDate Advertising. odst. 45.

35 Tímto místem je dle Soudního dvora místo, „,...obecně místo jejího obvyklého bydliště. Osoba však může mít centrum svých zájmů také v členském státě, v němž nemá obvyklé bydliště, pokud jiné indicie, jako např́iklad výkon profesní činnosti, mohou prokázat zvláště úzkou vazbu k tomuto státu.“'Tamtéž, odst. 49.

36 Zejména pokud je o požadavek ,vysoké předvídatelnosti“ pravidel pro určení př́slušnosti, jak je ostatně výslovně vyjádřen v preambuli nařizení Brusel I Bis odst. 15.

37 Význam určovatele šíření informace je v prostředí internetu snížen, protože vede k nejistotě, což Soudní dvůr EU reflektuje. Následně však namísto kompenzace tohoto nedostatku (z pohledu pravidel mezinárodního práva soukromého) a volby přístupu, který pomůže právní jistotu zvýšit, v podstatě rezignuje a zavádí přístup, který na právní jistotě neprridává, spíše naopak. Srov. KUIPERS, J. Joined Cases C-509/09 \& 161/10, eDate Advertising v. X and Olivier Martinez and Robert Martinez v. MGN Limited, Judgment of the Court of Justice (Grand Chamber) of 25 October 2011. Common Market Law Review, 2012, Issue 3, s. 1220.

38 Srov. ROZEHNALOVÁ, N., VALDHANS, J., DRLIČKOVÁ, K., KYSELOVSKÁ, T. Mezinárodníprávo soukromé Evropské unie (Nařzeni Řim I, Nařizeni Řim II, Nař́zeni Brusel I). 1. vyd. Praha: Wolters Kluwer ČR, 2013, 448 s., s. 225.

39 Viz článek 5 směrnice 2006/114 a článek 11 směrnice 2005/29. 
zajištění nápravy přímo v dotčené věci ve vazbě na dotčenou osobu. Zároveň se jedná o obranu, která nevyžaduje zprostředkování s rizikem možnosti uvážení, zda k prosazování unijních standardů pristoupit, či nikoliv. V případě nekalé soutěže vše výše uvedené bereme za zcela samozřejmé. Ve vztahu k nekalým obchodním praktikám tomu už tak s ohledem na veřejnoprávní charakter úpravy nemusí být.

$\mathrm{V}$ případě spotrebitelských smluv obsahuje nařízení Brusel I bis pravidla stanovící speciální pravomoc. Projevuje se zde všeobecný konsens prostupující unijním právem jako celkem, že spotřebitele je nutno rozumně (tj. nikoliv absolutně) chránit. Tato pravidla umožňují spotřebiteli žalovat ze spotřebitelské smlouvy druhou stranu bud' u soudů členského státu, v němž má žalovaná strana bydliště, nebo u soudu místa bydliště spotřebitele. ${ }^{40}$ Vlastní úprava těchto pravidel spadá spíše do oblasti spotřebitelského práva, nebylo by proto systematické se jejímu rozboru na tomto místě věnovat. ${ }^{41}$

Problém spatrujeme jinde. Nekalosoutěžní praktiky, jakož i nekalé obchodní praktiky, přesahují rámec samotného kontraktu a mohou být činěny již ve fázi prekonsenzuální. Situaci pak dále komplikuje fakt, že nekalé obchodní praktiky činěné v prekonsenzuální fázi zpravidla k uzavření smlouvy směřují. Vzniká proto otázka, jak k nim z pohledu nařízení Brusel I bis přistoupit. Možností je bud' široké chápání smlouvy zahrnující též fázi predsmluvní, nebo naopak uchopení tohoto problému prostřednictvím úpravy mimosmluvních závazků. Soudní dvưr EU tento problém řešil v rozhodnutí Henkel. ${ }^{42}$ Skutkový stav tohoto sporu spočíval v činnosti pana Henkela, německého státního př́slušníka, který v obchodních jednáních se zákazníky z Vídně použil nekalé obchodní praktiky rakouským právem zakázané. Pro toto jednání byl žalován ze strany jednoho z rakouských neziskových sdružení na ochranu spotřebitele.

Z pohledu právního je podstata problému v tom, že:

1. spor nemá prrímou vazbu na žádnou smlouvu, a

2. žalobu podává osoba třetí, která i kdyby smlouva skutečně uzavřena byla, nebude její smluvní stranou.

3. žaloba je podávána ještě předtím, než vznikne skutečná škoda, ve fázi, kdy je podávána má preventivní charakter. ${ }^{43}$

4. sdružení na ochranu spotřebitele neprosazuje zájem vlastní, ale zájem veřejný.

40 V článcích 17 až 19 nařízení Brusel I bis.

41 Odkazujeme proto na odbornou literaturu. Např. ROZEHNALOVÁ, N., VALDHANS, J., DRLIČKOVÁ, K., KYSELOVSKÁ, T. Mezinárodni právo sonkromé Evropské unie (Nařzení Rím I, Nařzeni Rím II, Nařzenini Brusel I). 1. vyd. Praha: Wolters Kluwer ČR, 2013, 448 s., s. 273 a násl.; či PAUKNEROVÁ, M. Evropské mezinárodní právo soukromé. 1. vyd. Praha: C. H. Beck, 2008, 441 s., s. 146 a násl.

42 Rozsudek Soudního dvora (šestého senátu) ze dne 1. řijna 2002. Verein für Konsumenteninformation proti Karlu Heinzi Henkelovi. Věc C-167/00.

43 Nutno zdůraznit, že z pohledu cílů sledovaných Evropskou unií ve vztahu k ochraně spotřebitele mají preventivní žaloby či opatření obecně mimořádný význam, jelikož pro dotčené osoby bude zpravidla lepši škodě předcházet, než ji následně složitě právní cestou řešit. Viz WILMAN, F.G. The end of the absence? The growing body of EU legislation on private enforcement and the main remedies it provides for Common Market Law Review. 2016, Issue 4, s. 915. 
Aktivaci speciálních pravidel pro určení pravomoci soudů v této věci s mezinárodním prvkem brání bod 2. z přehledu výše. Problém specifikovaný v bodě 1 . by totiž bylo jinak možné překonat širokým pojetím „smlouvy“ tak, že zahrnuje i předsmluvní jednání. Uplatnění pravidel pro určení pravomoci podle ustanovení pro mimosmluvní závazkové vztahy brání bod 2 a 3., škoda totiž ještě nevznikla, jen více či méně reálně hrozí. Navíc by vznikla jinému subjektu. Použití nařízení Brusel I bis v prrípadě bodu 4. brání fakt, že se týká pouze věcí občanskoprávních a obchodních a nezasahuje do oblasti práva veřejného.

Na straně druhé je ale faktem, že spotřebitelské sdružení je soukromoprávní osobou, která není nadána žádným speciálními pravomocemi či pověřena výkonem veřejné moci. I kdybychom vzali za své široké pojetí konceptu smlouvy, jakože přístup unijního práva takový v současné době není, ${ }^{44}$ nelze do tohoto konceptu žádným způsobem zahrnout osobu, která smluvní stranou není, nikdy nebyla a ani nebude. ${ }^{45}$ Nadto z již existující judikatury Soudního dvora EU vyplývá, že se úprava deliktů a kvazideliktů v nařízení Brusel I bis týká všech otázek, které směřují k uplatnění odpovědnosti žalovaného a které nejsou záležitostmi, jež se týkají smluv a pravidel pro ně stanovených. ${ }^{46}$ A konečně, pokud jde o to, že škoda dosud nevznikla, pak z interpretace článku 7 odst. 3 nař́ízení Brusel I bis požadavek skutečného vzniku škody nevyplývá jako předpoklad jeho aplikace, ani není rozhodujícím faktorem pro určení pravomocného soudu, což jasně dokazuje i případ Shevill, který byl rozebírán v kapitole předchozí. ${ }^{47}$

Preventivní žaloby na ochranu spotřebitele před nekalými obchodními praktikami, které byly podány sdruženími na ochranu spotřebitele, proto jsou věcí deliktní či kvazideliktní odpovědnosti a pravomoc v nich je určována na základě nařízení Brusel I bis, ${ }^{48}$ což ostatně potvrzuje i aktuální judikatura Soudního dvora EU. ${ }^{49}$

44 Srov. stanovisko generálního advokáta Saugmandsgaarda „Ačkoliv se pojem smluvního závazkovébo vątabu neomezuje na závazkové vataby mezi úáastníky ř́zení, znamená prinejmenšim konkéétni a existujici závazek..." Stanovisko generálního advokáta H. Saugmandsgaarda Øe ze dne 2. června 2016. Verein für Konsumenteninformation v. Amazon EU Sàrl. Věc C-191/15. odst. 50.

45 Nadto tato osoba sama není v postavení spotřebitele.

46 Tamtéž, odst. 36.

47 Tamtéž, odst. 46.

48 ROZEHNALOVÁ, N., VALDHANS, J., DRLIČKOVÁ, K., KYSELOVSKÁ, T. Mezinárodni právo soukeromé Evropské unie (Nařzeni Rím I, Nařzeni Řim II, Nařzení Brusel I). 1. vyd. Praha: Wolters Kluwer ČR, 2013. 448 s., s. 225.

49 Viz rozsudek Soudního dvora (třetího senátu) ze dne 28. července 2016. Verein für Konsumenteninformation v. Amazon EU Sàrl. Věc C-191/15. odst. 38. 


\section{Určení rozhodného práva ve věcech nekalé soutěže a nekalých obchodních praktik}

Kolizní úprava sledované problematiky je přímočařejší tím, že problematiku nekalé soutěže, na rozdíl od úpravy procesní, výslovně upravuje. Je to důsledkem historického vývoje, který vedl k identifikaci nekalé soutěže jako jedinečného a samostatného mimosmluvního závazku, který vyžaduje svou vlastní kolizní úpravu. ${ }^{50}$ Právní úprava je v unijním právu obsažena v nařízení Rím II v ustanovení článku 6, který zahrnuje jak oblast soukromoprávní (nekalou soutěž), tak i oblast veřejnoprávní (hospodářskou soutěž v užším pojeti). ${ }^{51}$ Spojujícím prvkem obou těchto částí je to, že tato právní úprava poskytuje ochranu soukromoprávním nárokům z obou uvedených oblastí soutěžního práva. ${ }^{52}$

Z pohledu koncepčního lze konstatovat, že právní úprava kolizní problematiky nekalé soutěže v nařízení Ř́m II ${ }^{53}$ není postavena na hledisku zájmů státư, ale vychází z odlišných a pevně daných kritérií, v jejichž středu leží individuální zájmy spotřebitelů a soutěžiteliu. ${ }^{54}$ Politika státu a potažmo i Evropské unie se přesto znatelně projevuje, jak ostatně deklaruje i preambule tohoto nařízení, když vymezuje Unií sledovaný cíl, jímž je ochrana soutěžitele, spotřebitele a veřejnosti a řádného fungování tržního hospodářství, ${ }^{55} \mathrm{kdy}$ takto pojatý cíl lze chápat též jako projekci zájmu veřejného. ${ }^{56}$ S ohledem na to, že nařízení Rím II používá pojem „nekalá soutěž“, je nutné upozornit na povinnost autonomního výkladu. ${ }^{57}$ Jeho význam tudíž není nijak spjat s významem tohoto pojmu v právu českém. Na straně druhé je nutné vykládat nařízení Řím II ve vaz-

50 Srov. DYER, A. Unfair Competition in Private International Law. in Recueil des Cours de l'Académie de droit international de La Haye. 1988 Vol. 211., s. 431.

51 Patrně je to též důsledek trendu jistého sbližování přístupu k hospodářské soutěži v unijním právu s přístupy, které jsou tradiční v právu Spojených států amerických, kde striktní rozdíl mezi nekalou soutěží a hospodářskou soutěží není pocit'ován a kde úprava nekalé soutěže mírí na prostředky omezování soutěže, zatímco soutěž hospodářská na účinky. Tamtéž, s. 403.

52 Srov. ROZEHNALOVÁ, N., VALDHANS, J., DRLIČKOVÁ, K., KYSELOVSKÁ, T. Meżnárodní právo soukromé Evropské unie (Nařzeni Řim I, Nařzeni Ř́m II, Nařżeni Brusel I). 1. vyd. Praha: Wolters Kluwer ČR, 2013. 448 s., s. 177.

53 Nařízení Evropského parlamentu a Rady (ES) č. 864/2007 ze dne 11. července 2007 o právu rozhodném pro mimosmluvní závazkové vztahy.

54 SYMEONIDES, S. Rome II and Tort Conflicts: Missed Opportunity. American Journal of Comparative Law 2008, Issue 1, s. 183 a 184.

55 Preambule nařízení Rím II odst. 21.

56 Soudní dvưr EU hovoří o zájmu kolektivním, dle jeho názoru platí, že: „, cílem čl. 6 odst. 1 uvedeného nař̌̉ení [nařízení Rím II. - vloženo autorem] je chránit kolektivní zájmy - presahujicí rámec vz̧tabũ mez̧i stranami sporu tím, že stanovi pravidlo konkrétně prizpuisobené tomuto účelu." Viz výše citovaný případ C-191/15, odst. 45.

57 K tomu viz PAUKNEROVÁ, M. Evropské mezinárodni právo sonkromé. 1. vyd. Praha: C. H. Beck, 2008, 441 s., s. 91; dále též KYSELOVSKÁ, T., ROZEHNALOVÁ, N. a kol. Roẓhodování Soudního dvora EU ve vécech príslušnosti (analýza roz̧odnuti dle Nař́zeni Brusel Ibis). 1. vyd. Brno: Masarykova univerzita, 2014, 514 s., s. 34 a násl. 
bě na jiné nástroje unijního práva, včetně nařízení Brusel I bis. Instituty a pojmy rozebírané výše při výkladu nařízení Brusel I bis proto mají svůj odraz i v rámci kolizní problematiky rozebírané na tomto místě.$^{58}$ Nebudou zde z tohoto důvodu znovu opakovány.

V souvislosti s rozebíranou problematikou považujeme za nezbytné upozornit na \ 2973 NOZ, který stanoví limit pro aplikaci českých nekalosoutěžních pravidel. ${ }^{59}$ Toto ustanovení není kolizní normou, zabraňuje pouze extrateritoriálnímu uplatňování nového občanského zákoníku. Nebrání však použití občanského zákoníku tehdy, pokud na něj odkáže určitá kolizní norma. Kolizní problematika v této oblasti je řešena výlučně unijním právem v nařízení Řím II, nikoliv českým občanským zákoníkem.

Rozhodným právem je dle nařízení Řím II právo země, ve které:

1. dochází nebo

2. pravděpodobně dojde

k narušení soutěžních vztahů nebo společných zájmů spotřebitelů.

Právní úprava má tedy preventivní charakter, ${ }^{60}$ obdobně, jako to pro oblast procesní bylo dovozeno judikatorně Soudním dvorem EU v již rozebíraném př́padu Henkel. Pokud ovšem jednání $z$ nekalé soutěže postihuje výlučně zájmy určitého soutěžitele, použije se obecný článek 4 nařízení Řím II a na jeho základě určené právo, jímž je bud' lex loci damni infecti nebo lex domicili commissi. Tento postup príichází v úvahu v prrípadě podplácení, odlákávaní zaměstnance, bojkotu určitého soutěžitele apod. ${ }^{61} \mathrm{~V}$ literatuře se uvádí, že důvodem je relativně omezené narušení trhu, ${ }^{62}$ domníváme se však, že přesnější je vycházet $z$ toho, že takovým jednáním nebyl aktivován, respektive neprevažuje zájem veřejný, ale zájem soukromý, a z toho důvodu lze použít obecné pravidlo pro určení rozhodného práva.

58 Viz např. výše citovaný př́pad C-191/15, kde v odst. 38 a 39 Soudní dvůr EU povinnost soud konstatuje: „Soudni dvir již v kontextu Umluvy ze dne 27. zárí 1968 o soudni př̌slušnosti a výkonu rozhodnutí v občanských a obchodních věcech... rozhodl, že preventivní žaloba podaná sdružením na ochranu spotrebitelu za účelem dosaženi zákazu

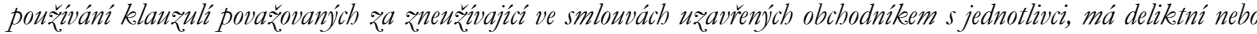
kvazideliktni povahu ve smyslu čl. 5 bodu 3 této úmluvy... Ve světle cíle soudržnébo použiváni pripomenutébo v bodě 36 tohoto rozsudku je pritom úvaha - podle keteré se v oblasti ochrany spotrebiteli mimosmluvni odpovédnost vątahuje rovněž na porušeni právního rádu vyplývajici zpouživáni zneuživajicich klauquli a úkolem sdruženi na ochranu spotrebiteli je takovým klauzulim bránit... - v plném rozsahu prenositelná na výklad nař́zeni Řim I a Rim II. Je tak treba konstatovat, že se žaloba na żdrženi se jednáni upravená smèrnici 2009/22 týká mimosmluvni odpovédnosti vyplývajici ze skutečnosti vedouci ke vaniku škody ve smyslu rtoly II nařżeni Rím II. “

59 \2973 NOZ stanoví: „Ustanoveni této hlavy se nevztabuji na jednáni v rozsabu, v jakém má účnky v żabranicú, pokud z. mezinárodnich smluv, jimiž je Ceská republika vázána a keteré byly vyblášeny ve Sbirce mezinárodních smluv, nevyplývá nèco jinébo."

60 ROZEHNALOVÁ, N., VALDHANS, J., DRLIČKOVÁ, K., KYSELOVSKÁ, T. Mezinárodni právo soukromé Evropské unie (Nařzeni Rím I, Nařzeni Řim II, Nařzeni Brusel I). 1. vyd. Praha: Wolters Kluwer ČR, 2013, 448 s., s. 177.

61 Ibidem, s. 179.

62 Ibidem, s. 179. 
Judikatura Soudního dvora EU v oblasti kolizní problematiky nekalé soutěže a nekalých obchodních praktik je omezená. Aktuálním případem je v tomto článku již citované rozhodnutí Soudního dvora EU ze dne 28. července 2016 ve věci Verein für Konsumenteninformation v. Amazon EU Sàrl týkající se otázky kvalifikace závazků uplatněných v rámci žaloby na zdržení se jednání, jejímž cílem je zakázat používání nepřiměřených ustanovení ve smlouvách uzavíraných se spotřebiteli. Spor byl iniciován rakouským sdružením na ochranu spotřebitele proti lucemburské společnosti Amazon EU Sàrl působící na dálku prostřednictvím německých webových stránek též v Rakousku. Žaloba byla podána proti nepřiměřeným podmínkám jejího webového obchodu, které tato společnost používala ve svých obchodních podmínkách s tím, že žalováno bylo na zdržení se tohoto jednání. Použitelnost článku 6 odst. 1 nařízení Rím II na tuto situaci byla dovozena s ohledem autonomní pojetí nekalé soutěže pro potřeby nařízení Rím II, když podle generálního advokáta Saugmandsgaarda se toto ustanovení vztahuje na „každý úkon, který by mobl żmènit vžtaby mezi účastniky na trhu, bud' mezi konkurenty, nebo vǐci spotrebitelüm kolektivně.“ ${ }^{3} 3$ Soudní dvůr EU tuto argumentaci přijal. Je-li pojetí nekalé soutěže podle nařízení Rím II takto široké, pak nutně musí zahrnovat též používání nepřiměřených podmínek vkládaných do obchodních podmínek, jelikož i ony narušují kolektivní zájmy spotřebitelů jako kategorie a ovlivňují podmínky hospodářské soutěže. ${ }^{64}$

\section{Závěr}

Řešení problémů v oblasti určování mezinárodní pravomoci soudů a rozhodného práva se neobejde bez znalosti doktríny. Pravidla obsažená v nařízení Brusel I bis a nařízení Rím II totiž vykazují vysokou míru obecnosti. Nařízení Brusel I bis problematiku nekalé soutěže výslovně nezmiňuje vưbec, použije se proto alternativního pravidla stanovící kritéria pro soudní pravomoc pro mimosmluvní závazkové vztahy obecně obsažená v článku 7 odst. 2 tohoto nařízení. Žalobu je proto možné podat rovněž u soudu místa, kde došlo nebo může dojít ke škodné události. Výklad tohoto ustanovení je problematický, jelikož škodná událost může být chápána jako místo, kde škoda vznikla, nebo místo, kde došlo ke vzniku události, jež škodu zapříčinila. Pro potřeby nekalé soutěže je místo vzniku škody všude tam, kde se obchodník účastní hospodářské soutěže a je zde ve svých zájmech poškozen. V takto určených státech ovšem může být projednána újma, kterou zde utrpěl, nikoliv újma celá jako v prípadě určovatele druhého. Pravidlo omezující rozsah škody, kterou lze v určitém státě projednat, je ovšem modifikováno pro újmu způsobenou v prostředí internetu použitím doplňkového kritéria v podobě centra zájmů

63 Viz stanovisko generálního advokáta H. Saugmandsgaarda Øe ze dne 2. června 2016. Verein für Konsumenteninformation v. Amazon EU Sàrl. Vèc C-191/15. odst. 73.

64 Viz rozsudek Soudního dvora (třetího senátu) ze dne 28. července 2016. Verein für Konsumenteninformation v. Amazon EU Sàrl. Věc C-191/15. odst. 42 a stanovisko generálního advokáta H. Saugmandsgaarda Øe ze dne 2. června 2016. Verein für Konsumenteninformation v. Amazon EU Sàrl. Věc C-191/15. odst. 73. 
obchodníka. V každé zemi, kde takové centrum zájmů má, typicky to bude všude tam, kde podniká, bude moci žalovat na celou utrpěnou újmu. V ostatním zůstává pravidlo nezměněno.

Kolizní úprava v nařízení Ř́m II výslovnou úpravu nekalé soutěže obsahuje. Výklad pojmu pro potřeby tohoto nařízení je autonomní na vnitrostátním právu a zahrnuje též problematiku nekalých obchodních praktik upravených unijním právem. Dopadá též na fázi předsmluvní (použije se i bez vazby na konkrétní smlouvu), je-li cílem žaloby zakázat používání nepřiměřených ustanovení ve smlouvách uzavíraných se spotřebiteli. Rozhodným právem je podle článku 6 odst. 1 nařízení Řím II právo toho státu, kde dochází nebo kde pravděpodobně dojde k narušení soutěžních vztahů nebo společných zájmů spotřebitelů s výjimkou situací, které nemají obecný dopad v tom smyslu, že se týkají jen jednoho jediného soutěžitele. $V$ takovém př́padě se použije postup upravený článkem 4 nařízení Rím II a rozhodným právem obecně bude právo země, kde škoda vznikla. 